\title{
Uremic neuropathy: an overview of the current literature
}

Celeste Rodovalho Soares de Camargo ${ }^{1}$

(iD) Jean Henri Maselli Schoueri ${ }^{1}$

(iD) Beatriz da Costa Aguiar Alves ${ }^{2}$

(iD) Glaucia R. L. da Veiga ${ }^{2}$

(iD) Fernando L. A. Fonseca ${ }^{2,3}$

(iD) Marcelo R. Bacci ${ }^{1}$

1. Department of Integrated Clinical Discussions, ABC Medical School, Santo André, SP, Brasil 2. Laboratory of Clinical Analysis, ABC Medical School, Santo André, SP, Brasil 3. Pharmaceutical Sciences Department, Federal University of São Paulo, Diadema, SP, Brasil

http://dx.doi.org/10.1590/1806-9282.65.3.469

\section{SUMMARY}

INTRODUCTION: Peripheral neuropathy is a disorder that affects the cell body, axon or myelin of motor or peripheral sensory neurons and occurs in 60-100\% of patients who are submitted to dialysis due to chronic kidney disease. Uremic neuropathy (UN) is attributed to the accumulation of organic waste, evident in patients with reduced glomerular filtration rate.

OBJECTIVES: This review aims to make clinical characteristics of uremic neuropathy evident enabling early diagnosis and treatment. METHODS: This is a literature review of articles published on PubMed over the last 10 years using "Uremic Neuropathy" as "Title/Abstract".

RESULTS: A total of nine articles that met the inclusion criteria were included. UN is a distal symmetric sensorimotor polyneuropathy that occurs due to the accumulation of uremic toxins associated with an oxidative stress-related free radical activity. Hyperkalemia is thought to play an important role in its pathophysiology. Diagnosis depends on nerve conduction studies, and treatment includes dialysis or renal transplant.

CONCLUSION: Clinical presentations of UN are broad and non-specific; nonetheless, it is important to detect early changes in order to avoid its progression. The earlier UN is diagnosed and treated, the more successful are the clinical outcomes.

KEYWORDS: Neural conduction. Dialysis. Kidney Transplantation. Peripheral Nervous System Diseases. Uremia/complications.

\section{INTRODUCTION}

Peripheral neuropathy (PN) is a disorder that affects the cell body, axon or myelin of motor or peripheral sensory neurons and can respectively be classified as neuropathological, axonal or demyelinating. This condition is either hereditary or acquired and may be further subdivided into sensory, motor or autonomic ${ }^{1}$. PN has a large spectrum of causes (such as nutritional deficiencies and toxic neuropathies ${ }^{2}$ as well as clinical presentations ${ }^{3}$; however, constant and recurring pain occurs in almost all types of this disorder ${ }^{4}$.

The overall prevalence of peripheral neuropathy is $2.4 \%$. However, this number increases exponentially in certain age groups, and it may even be an under-

DATE OF SUBMISSION: 31-Jul-2018

DATE OF ACCEPTANCE: 05-Aug-2018

Corresponding Author: Marcelo Rodrigues Bacci

Av. Príncipe de Gales, 821 - Vila Príncipe de Gales, Santo André, São Paulo, Brasil - CEP 09060650

Phone: +5511981937005

E-mail:mrbacci@yahoo.com 
estimate since traumatic causes are not included in this percentage ${ }^{3}$.

Peripheral neuropathy occurs in $60-100 \%$ of patients who are submitted to dialysis due to chronic kidney disease (CKD) ${ }^{5}$. Uremic neuropathy (UN) occurs when renal dysfunction impairs filtration, leading to the accumulation of organic waste. This is evident in patients with reduced glomerular filtration rate (GFR) usually attributed to end-stage renal disease (ESRD) ${ }^{6}$.

This review aims to make the clinical characteristics of uremic neuropathy evident enabling early diagnosis and treatment in order to prevent the effects of the advanced stages of this condition. The secondary purpose is to discuss the prognosis of uremic neuropathy based on data hinted in literature.

\section{METHODS}

This is a literature review of articles published on PubMed over the last 10 years using "Uremic Neuropathy" as "Title/Abstract". A total of 15 articles were found and 11 of them were available. Then, 9 articles were included as they met the inclusion criteria (Figure 1) - they were clinical studies and discussed uremic neuropathy.

\section{RESULTS}

\section{Prevalence}

In 1961, Martin and Tyler published the first report on uremic neuropathy in patients with hereditary intestinal nephritis with distal sensory-motor polyneuropathy ${ }^{7,8}$. Asbury et al, in 1963 used the term uremic polyneuropathy to describe distal sensorimotor changes due to uremic toxins. Uremic neu- ropathy is more frequent in males than in females ${ }^{8}$ and is a common condition: studies have shown that it's prevalence varies from $50-100 \%$ in patients with chronic kidney disease ${ }^{7,9-11}$. This large range of values is due to the application of different criteria for the diagnosis of UN. The prevalence of UN in the pediatric population is unknown ${ }^{10}$.

\section{Pathology and pathophysiology of Uremic Neuropathy}

UN is a distal symmetric sensorimotor polyneuropathy that typically affects lower limbs ${ }^{7,12}$ and is due to length-dependent axonal degradation and secondary focal loss of myelin sheaths ${ }^{7,8}$. This is considered a demyelinating condition which leads to axonal degeneration and loss ${ }^{8-10}$.

The accumulation of uremic toxins (the "middle toxins": guanidine compounds, parathyroid hormone, and myoinositol) ${ }^{10,11}$ associated to oxidative stress-related free radical activity causes motor, sensory and autonomic nerve damage which leads to UN $8,13,14$. Although this exact mechanism remains unknown ${ }^{10}$, there are hypotheses supporting the role of electrolytes in this process ${ }^{8,9,12}$. Hyperkalemia and hyperphosphatemia cause chronic uremic depolarization of nerves, contributing to the development of UN ${ }^{8,12}$. This occurs because potassium disrupts the normal ionic gradient and therefore activates calcium-mediated processes leading to axonal death ${ }^{9}$.

UN is usually asymptomatic until renal function is under $15 \%$, and glomerular filtration is lower than $10-12 \mathrm{ml} / \mathrm{min}$, which usually happens $10-15$ years after the onset of the underlying disease, such as diabetic neuropathy $7,8,10,11$. This type of neuropathy is one of the most frequent neurological manifestations of end-stage renal disease (ESRD) ${ }^{11}$.

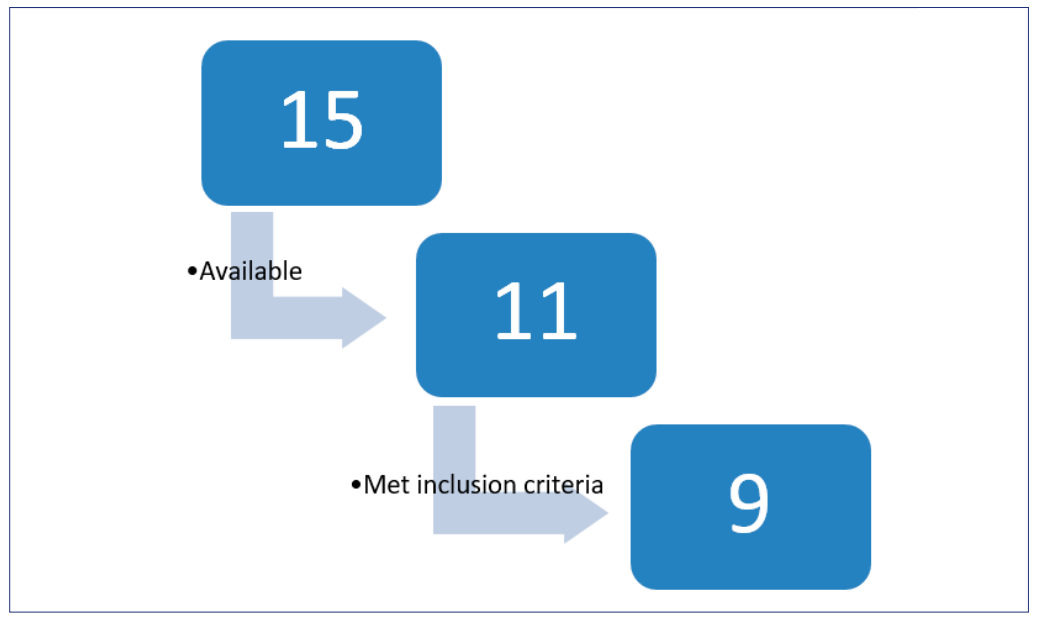

FIGURE 1. SELECTION PROCESS OF ARTICLES INCLUDED IN THIS REVIEW. 
Both slowly and rapidly progressing sensorimotor axonal neuropathies are relatively common ${ }^{10}$. However, there have also been reports of fulminant motor neuropathies, which occurred under specific clinical conditions such as sepsis and severe $\mathrm{CRF}^{8}$.

Hyperkalemia and hyperphosphatemia increase the risk of developing $\mathrm{UN}^{9}$. Other risk factors for UN are diabetes, advanced age and low creatinine and clearance ${ }^{10}$.

A schematic representation of uremic neuropathy causes can be seen in Figure 2 .

\section{Symptoms of Uremic Neuropathy:}

Sensory and motor changes due to Uremic

Neuropathy

Symptoms of UN vary, but it typically presents as a slowly progressing sensorimotor axonal neuropathy ${ }^{9}$ which advances proximally, starting from the lower limbs and may spread to upper extremities ${ }^{7}$. Early symptoms are paresthesia, paradoxical heat sensation, restless leg syndrome, increased pain sensation, and cramps ${ }^{7,9}$. Long-term symptoms include weakness, impaired deep tendon reflexes, imbalance, numbness, and atrophy of the lower limbs ${ }^{7-11}$.

\section{Nerve conduction and quantitation of sensory loss}

Quantitation of sensory loss and nerve conduction is one of the main tools used to evaluate UN, as well as electromyography ${ }^{11}$. In patients suffering from this condition, nerve conduction velocity usually falls to $50-60 \%$ of normal values ${ }^{8}$; however, light

FIGURE 2. REPRESENTATIVE SCHEME OF UREMIC NEUROPATHY POSSIBLE CAUSES

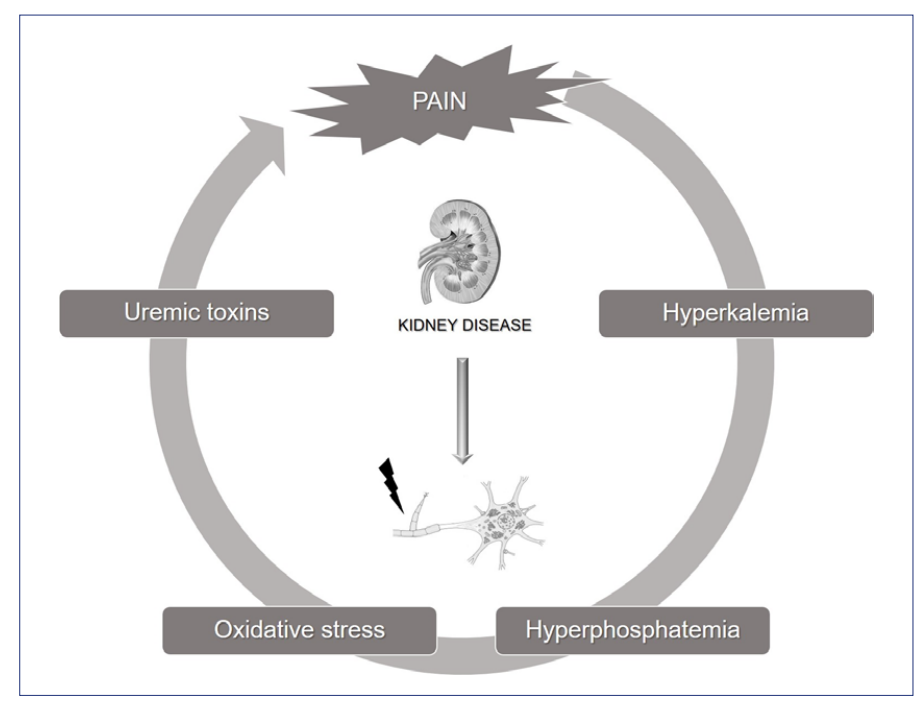

touch and vibratory perception thresholds are more sensitive to evaluate either progression or recovery of UN than conduction velocity ${ }^{8}$.

Some patients suffer thermal sensitivity impairment before they have sensory and motor damage. The number of functional axons in a nerve is evaluated according to changes in the amplitude of muscle response and sensory nerve action potentials ${ }^{8}$. The myelination of nerve fibers and their density is tested by velocity conduction. The most common morphological change in UN is the loss of large myelinated fibers, and positive neuropathic symptoms tend to correlate with quantitative results in conduction and sensory tests ${ }^{8}$.

After nerve transplantation, there is an increase in nerve conduction due to remyelination ${ }^{8}$. Studies have shown that motor nerve conduction (MCV) is a significant predictor of mortality ${ }^{13}$ in hemodialysis patients and achieves statistically significant values: $(\mathrm{HR}=0.92$; CI $(0.86-0.99) ; \mathrm{p}<0.05){ }^{15}$. MCV correlates significantly with dialysis dose; however, further investigation is needed in order to confirm this hypothesis ${ }^{13}$.

\section{Uremic Neuropathy in Children and Teenagers}

The prevalence of UN in children is unknown ${ }^{10}$, and this population usually does not present clinical evidence of UN; however, nerve conduction is altered, likewise in adults ${ }^{8}$. Authors showed that mean peroneal motor nerve conduction velocity (MNCV) was significantly decreased in children with mild renal failure (serum creatinine concentration, 1.5 to 2.9 $\mathrm{mg} / \mathrm{dL}$, normal range: $0.8-1.2 \mathrm{mg} / \mathrm{dL}$ ), while ulnar MNCV was significantly decreased only when the serum creatinine value was at least $9 \mathrm{mg} / \mathrm{dL}$. Within a year of renal transplantation, ulnar MNCV tends to return to normal values, and it takes 3 years for peroneal MNCV to go back to baseline values.

These parameters could potentially be used to evaluate the development of UN. However, they are only meaningful when renal function is very low or after a long period of time. Therefore, the periodic measurement of nerve conduction velocity is not useful to follow UN in children undergoing chronic hemodialysis ${ }^{8}$.

\section{Uremic Optic Neuropathy}

Uremic optic neuropathy (UON) is a possible manifestation of UN that causes sudden vision deterioration and involves focal edema of the optic nerve 
head ${ }^{14}$. Other related ophthalmic disorders include swelling of optic nerve heads, blurred margins of the optic disks seen using an ophthalmoscope. This disease should be taken into consideration as a possible diagnosis when patients with advanced chronic kidney failure present vision deterioration.

Seo et al. ${ }^{14}$ described a patient suffering from UON who presented all the manifestations mentioned above, and the visual-evoked potential tests revealed reduced amplitude and increased latency in one of the eyes. This patient was treated with hemodialysis and corticosteroids, and his visual acuity and visual field improved, and the optic disk swelling was resolved.

The pathogenesis of UON is not well known. However, it has been shown to be related to the accumulation ofthat dialyzable toxin metabolites. Hemodialysis in combination to corticoids is the standard treatment for $\mathrm{UON}^{14}$.

\section{Diagnosis}

The gold standard method to diagnose UN is a nerve conduction study ${ }^{7,9}$. Complementary methods include neurological assessment and biopsy of distal axons ${ }^{12}$. Since some UN symptoms are subjective and cannot be quantified using clinical tests, it might also be interesting to include psychological evaluation in order to investigate $\mathrm{UN}^{15}$. UN, however, may remain asymptomatic for a long time and only cause symptoms when severe damage has already been done. Therefore, an investigation should take place even in asymptomatic patients who present risk factors for $\mathrm{UN}^{7}$.

\section{Treatment of Uremic Neuropathy}

Treatments that may reverse the effect of UN and improve nerve function are dialysis and renal transplantation ${ }^{7,9,10}$. Studies have shown a more significant reduction in the progression of UN due to an increase in dialysis dose, be it peritoneal or conventional dialysis ${ }^{9}$. It is controversial whether patients submitted to peritoneal dialysis have inferior results in the treatment of UN compared to those submitted to conventional hemodialysis ". Hemodiafiltration is another therapeutic option that also benefits motor nerve excitability.

Renal transplantation is the only definite treatment that interrupts the progression of UN and reverts symptoms. It is important to note that results are inversely proportional to the disease duration prior to the transplant: a shorter disease time leads to better post-transplant clinical outcomes ${ }^{10}$. Nonetheless, in patients who may not undergo this procedure, either due to clinical restrictions or personal denial, effective dialysis is definitely a good therapeutic option ${ }^{11}$ as it also normalizes most nerve excitability parameters ${ }^{8}$.

\section{Comparison of uremic neuropathy with other types of neuropathies:}

There are many different types of neuropathies other than Uremic, including Diabetic, Alcoholic, Chronic Inflammatory, and Infectious. Below is a comparative table with the symptoms and treatments of these main types of neuropathies.

\section{TABLE 1. ASSOCIATION OF DIFFERENT TYPES OF NEUROPATHY AND ITS TREATMENTS}

\begin{tabular}{|c|c|c|}
\hline NEUROPATHY & MAIN SYMPTOMS & TREATMENT \\
\hline Uremic Neuropathy & $\begin{array}{l}\text {-Pain, numbness, and tingling in feet and legs; } \\
\text {-Cramps, muscle twitches, or increased pain } \\
\text { sensation in the feet and legs; } \\
\text {-Muscle weakness }{ }^{\mathbf{1 6}}\end{array}$ & $\begin{array}{l}\text {-Dialysis } \\
\text {-Kidney Transplant }{ }^{\mathbf{1 6}}\end{array}$ \\
\hline Diabetic Neuropathy & $\begin{array}{l}\text {-Slowly and progressive primarily sensory defi- } \\
\text { cit following a "stocking-glove distribution" } \mathbf{1 7}\end{array}$ & $\begin{array}{l}\text {-Treatment can range from lifestyle modification and strict glucose control } \\
\text { to the use of immunosuppressant medications } \mathbf{1 7 , 1 8}\end{array}$ \\
\hline Alcoholic Neuropathy & $\begin{array}{l}\text {-Painful paresthesia; } \\
\text {-Muscle weakness; } \\
\text {-Sensory and motor symptoms extend proxi- } \\
\text { mately into the arms and legs; } \\
\text {-Gait impairment may be present } \mathbf{1 9 , 2 0}\end{array}$ & $\begin{array}{l}\text { - Thiamine treatment has been shown not to be effective; } \\
\text { - Therapy ought to include cessation of alcohol ingestion, aiming at the } \\
\text { toxic target(s) of alcohol }{ }^{\mathbf{2 2}}\end{array}$ \\
\hline $\begin{array}{l}\text { Chronic Inflammatory } \\
\text { Neuropathy }\end{array}$ & $\begin{array}{l}\text {-Weakness is typically symmetric and charac- } \\
\text { teristically involves proximal and distal muscles; } \\
\text {-Sensory symptoms include numbness, } \\
\text { tingling, gait imbalance, and, at times, painful } \\
\text { paresthesias }{ }^{21}\end{array}$ & $\begin{array}{l}\text {-Steroids, plasma exchange, and intravenous immunoglobulin may be } \\
\text { used as } 1^{\text {st }} \text { line treatment options }{ }^{\mathbf{2 1}}\end{array}$ \\
\hline
\end{tabular}




\section{CONCLUSION}

$\mathrm{UN}$ is a prevalent condition, affecting 60 to $100 \%$ of patients who suffer from chronic kidney disease, depending on the classification criteria used. The exact mechanism of the demyelinating process leading to axonal degeneration and loss is still uncertain. However, electrolytes, such as potassium, have shown to play an important role in the pathophysiology of UN. Clinical presentations of UN are broad and may be non-specific; nonetheless, it is essential to detect early changes in order to diag- nose UN and avoid its progression. The earlier the signs and symptoms of UN are detected, the earlier UN is diagnosed using nerve conduction studies and treated with dialysis or renal transplant, leading to greater clinical success.

\section{ACKNOWLEDGMENTS}

This research did not receive any specific grant from funding agencies in the public, commercial, or non-profit sectors.

\section{RESUMO}

INTRODUÇão: A neuropatia periférica (NU) é um distúrbio que afeta o corpo celular, o axônio ou a mielina do motor ou neurônios sensoriais periféricos e ocorre em 60\%-100\% dos pacientes que são submetidos à diálise por doença renal crônica. A neuropatia urêmica é atribuída à acumulação de resíduos orgânicos, evidente em pacientes com taxa de filtração glomerular reduzida.

OBJETIVO: O objetivo desta revisão é fazer com que as características clínicas da neuropatia urêmica sejam evidenciadas, permitindo o diagnóstico e tratamento precoce.

MÉTODO: Esta é uma revisão da literatura de artigos publicados no PubMed nos últimos dez anos usando "Neuropatia Urêmica" como "Título/Resumo".

RESULTADOS: No total, foram incluídos nove artigos que atendem aos critérios de inclusão. A NU é uma polineuropatia sensório-motora simétrica distal que ocorre devido ao acúmulo de toxinas urêmicas associadas à atividade de radicais livres relacionados ao estresse oxidativo. A hipercalemia tem um papel importante na sua fisiopatologia. O diagnóstico depende de estudos de condução nervosa e o tratamento inclui diálise ou transplante renal.

CONCLUSÃO: As apresentações clínicas das NU são amplas e não específicas; no entanto, é importante detectar mudanças iniciais para evitar sua progressão. Quanto mais precoce for a detecção e tratamento da NU, melhor será o resultado clínico.

PALAVRAS-CHAVE: Condução nervosa. Diálise. Transplante de rim. Doenças do sistema nervoso periférico. Uremia/complicações.

\section{REFERENCES}

1. Marchettini $P$, Lacerenza $M$, Mauri E, Marangoni C. Painful peripheral neuropathies. Curr Neuropharmacol. 2006;4(3):175-81.

2. Staff NP, Windebank AJ. Peripheral neuropathy due to vitamin deficiency, toxins, and medications. Continuum (Minneap Minn). 2014;20(5 Peripheral Nervous System Disorders):1293-306.

3. Misra UK, Kalita J, Nair PP. Diagnostic approach to peripheral neuropathy. Ann Indian Acad Neurol. 2008;11(2):89-97.

4. International Modulation Society. 2007. Neuropathy, neuropathic pain, and painful peripheral neuropathy: many kinds, causes, and treatments [cited 2017 March 12). Available from: http://www.neuromodulation. com/fact_sheet_painful_peripheral_neuropathy

5. Mambelli E, Barrella M, Facchini MG, Mancini E, Sicuso C, Bainotti $S$, et al. The prevalence of peripheral neuropathy in hemodialysis patients. Clin Nephrol. 2012;77(6):468-75.

6. Cooper JD, Lazarowitz VC, Arieff Al. Neurodiagnostic abnormalities in patients with acute renal failure. J Clin Invest. 1978;61(6):1448-55.

7. Ghazan-Shahi S, Koh TJ, Chan CT. Impact of nocturnal hemodialysis on peripheral uremic neuropathy. BMC Nephrol. 2015;16:134.

8. Said G. Uremic neuropathy. Handb Clin Neurol. 2013;115:607-12.

9. Witzel II, Jelinek HF, Khalaf K, Lee S, Khandoker AH, Alsafar H. Identifying common genetic risk factors of diabetic neuropathies. Front Endocrinol (Lausanne). 2015;6:88.

10. Kandil MR, Darwish ES, Khedr EM, Sabry MM, Abdulah MA. A community-based epidemiological study of peripheral neuropathies in Assiut, Egypt. Neurol Res. 2012;34(10):960-6.
11. Deger SM, Reis KA, Guz G, Bali M, Erten Y. A case of an accelerated uremic neuropathy. Renal Fail. 2011;33(3):371-2.

12. Sinha AD, Agarwal R. Chronic renal disease progression: treatment strategies and potassium intake. Semin Nephrol. 2013;33(3):290-9.

13. Stosovic M, Nikolic A, Stanojevic M, Simic-Ogrizovic S, Radovic M, Jovanovic $D$, et al. Nerve conduction studies and prediction of mortality in hemodialysis patients. Ren Fail. 2008;30(7):695-9.

14. Seo JW, Jeon DH, Kang Y, Lee DW, Lee HJ, Yoo WS, et al. A case of endstage renal disease initially manifested with visual loss caused by uremic optic neuropathy. Hemodial Int. 2011;15(3):395-8.

15. Nowicki M, Zwiech R, Dryja P, Sobański W. Autonomic neuropathy in hemodialysis patients: questionnaires versus clinical tests. Clin Exp Nephrol. 2009;13(2):152-5

16. University of Chicago. Types of peripheral neuropathy - systemic / metabolic. 2017. [cited 2017 April 20]. Available from: http://peripheralneuropathycenter.uchicago.edu/learnaboutpn/typesofpn/systemic/ kidney.shtml.

17. Tracy JA, Dyck PJ. The spectrum of diabetic neuropathies. Phys Med Rehabil Clin N Am. 2008;19(1):1-26.

18. Schreiber AK, Nones CF, Reis RC, Chichorro JG, Cunha JM. Diabetic neuropathic pain: physiopathology and treatment. World J Diabetes. 2015;6(3):432-44.

19. Zeng $L$, Alongkronrusmee $D$, van Rijn RM. An integrated perspective on diabetic, alcoholic, and drug-induced neuropathy, etiology, and treatment in the US. J Pain Res. 2017;10:219-28. 
20. Chopra K, Tiwari V Alcoholic neuropathy: possible mechanisms and future treatment possibilities. Br J Clin Pharmacol. 2012;73(3):348-62.

21. Dimachkie MM, Barohn RJ. Chronic inflammatory demyelinating polyneuropathy. Curr Treat Options Neurol. 2013;15(3):350-66.

22. Mellion M, Gilchrist JM, de la Monte S. Alcohol-related peripheral neuropathy: nutritional, toxic, or both? Muscle Nerve. 2011;43(3):309-16.

23. Cashman CR, Höke A. Mechanisms of distal axonal degeneration in peripheral neuropathies. Neurosci Lett. 2015;596:33-50.

24. Smith HS. Treatment considerations in painful HIV-related neuropathy. Pain Physician. 2011;14(6):E505-24.

25. Prud'homme S, Nevens F, Casteels I. Bilateral simultaneous anterior ischemic optic neuropathy, an extrahepatic manifestation of hepatitis $C$ cured with direct acting antivirals. GMS Ophthalmol Cases. 2016;6:Doc05.

26. Benstead TJ, Chalk CH, Parks NE. Treatment for peripheral neuropathy associated with hepatitis C virus infection. 2017. [cited 2017 Apri 20]. Available from: http://www.cochrane.org/CD010404/NEUROMUSC treatment-for-peripheral-neuropathy-associated-with-hepatitis-c-virus-infection, 2014
27. Foundation for Peripheral Neuropathy. Lyme disease neuropathy. [cited 2017 April 20]. Available from: https://www.foundationforpn.org/ what-is-peripheral-neuropathy/causes/inflammatory-infectious/ lyme-disease/

28. Sigal LH, Williams S. A monoclonal antibody to Borrelia burgdorferi flagellin modifies neuroblastoma cell neuritogenesis in vitro: a possible role for autoimmunity in the neuropathy of Lyme disease. Infect Immun 1997;65(5):1722-8.

29. Radzišauskienè $D$, Ambrozaitis A, Marciuškienè E. Delayed diagnosis of lyme neuroborreliosis presenting with abducens neuropathy without intrathecal synthesis of Borrelia antibodies. Medicina (Kaunas). 2013;49(2):89-94

30. Nyati KK, Nyati R. Role of Campylobacter jejuni infection in the pathogenesis of Guillain-Barré syndrome: an update. Biomed Res Int. 2013:2013:852195.

31. Miljković-Selimović B, Lavrnić D, Morić O, Ng LK, Price L, Suturkova $L$, et al. Enteritis caused by Campylobacter jejuni followed by acute motor axonal neuropathy: a case report. J Med Case Rep. 2010;4:101. 